\title{
The Translation of Zhoushan Fishing Songs under the Background of Constructing the International Ecological Leisure Island
}

\author{
Guo Yutian ${ }^{1}$, Jiadai MAO ${ }^{2}$ \\ ${ }^{1}$ South Haida Road Dinghai, Zhejiang Ocean University, Hangzhoum \\ ${ }^{2}$ College of Foreign Languages Zhejiang Ocean University
}

*Corresponding Author: Guo Yutian, South Haida Road Dinghai, Zhejiang Ocean University, Hangzhou

\begin{abstract}
Because of Chinese and English's language and culture differences, as well as the Fishing Songs's creativity, the translation and relevant literature work of Zhoushan Fishing Songs are limited. Under the background of constructing an international ecological leisure island, the research of Zhoushan fishing songs' translation plays an important part in the advertising of Zhoushan ocean culture and the building of an international island image. This paper collects fishing song's translation text, studies on the translation model, and concludes the problems and resolves in the process of fishing songs translation. It aims at calling for the attention of relevant persons and departments and strengthen the advertisement of fishing songs's translation. Also, it attempts to promote the exchanging and advertising of Zhoushan characteristic island culture.
\end{abstract}

Keywords: Fishing song; Translation

\section{INTRODUCTION}

Originally, ballads are like mirrors reflecting the lives of labouring people and they are the crystallization of people's wisdom as well as the reflection and sediment of the local culture. Due to the special geographical conditions of Zhoushan, the history and culture of it are intimately related with the word "sea". And Zhoushan fishing songs are part of the culture of Zhoushan. With the communication between different countries becomes increasingly frequent, it is time to speed up the process of advertising the culture of Zhoushan islands without hesitation. However, presently it is a pity that there is almost no existence of the translation and research.

Hence, by researching and investigating to collect the fishing songs and the translated texts, this paper attempts to promote the translation and the research of Zhoushan fishing songs.

\section{Patterns of Translation Patterns}

According to the definition, Translation Pattern is the recapitulative description of the process of translation and seen as a standard of operational procedure of translation (Yang Chun,2001). In linguistics and translation studies, the existing patterns of translation deeply analyses the form of linguistic and psychology. No matter it is the pattern of Eugene A. Nida (Du Lili,2008), the pattern of Kade (Miao Ju, Gao Qian,2010), the pattern of Wales (Yang Chun,2001), Interpretive pattern (Zhang Jiliang,2011), or even the communicating pattern and the information processing pattern in psychology from Roger T. Bell (Bell,1991), all these promote a great success in language translation and offer ample information to researchers, to some extent.

Among these, information processing pattern divides the process of translation into two parts ---analysis and synthesis, each part including three different areas ---- syntax, semantics and pragmatics. Firstly, through reading, translators make a slight comprehension of the usage of language and then comprehend the meaning and application in certain circumstances. Eventually, translators make detailed adjustments and analyze the whole article in this kind of circumstance. There are many rare words and dialects in Zhoushan fishing songs. So in the process of analysis, translators are able to transform the original text into a text without features of dialect. When turning to the comprehensive stage, translators can adjust the information and to translate it with the features of second language. Therefore, the information processing pattern is more adoptable for translators to translate fishing songs, compared with other patterns. 


\section{THE DIFFICULTIES IN THE PRACTICE OF TRANSLATION}

\subsection{The Differences of Poetic Composition between Chinese and English}

Chinese poetry often uses rhyme, inversion and other writing techniques. Therefore, during Chinese to English translation, translators should pay extra attention to these differences.

\subsection{The Lack of Relevant Vocabulary}

Due to the differences between the language and the culture of Chinese and English, there are some words that can't be translate into English directly. Therefore, the content should be processed by the information processing pattern. What's more, Zhoushan fishing songs include a great many proper names of dried aquatic products. This kind of word would make translation more difficult.

\subsection{The Ellipses of the Complex and Meaningless Words}

Fishing songs have extensive use of onomatopoetic words and complex phrases. However, these expressions sometimes have no practical meaning or they are hard to understand by literal translation. Thus, it is something needs to be solved in the process of translation.

\subsection{The Application of the Information Processing Pattern in Translation}

When translating Antiphonal Fishing Song, “我系唱歌王, 问你龙王海底几张床? 又有几多金砖垫在床脚底？几多宫娥盖被上龙床？”, we can use the information processing pattern to analyze the syntax, semantics, and pragmatics of the original text. Through the analysis, it can be conclude that this poem uses a lot of inversion, and its sentence is syntactically reversed. After analyzing the text, translators can get a text without linguistic features. Next, in the process of synthesis, the translator could translate the text into English, according to the linguistic features of the second language (English) and the text without linguistic features which he gets in the former process. Therefore, the English translation of this poem is "I am folk song king. Let me ask you: how many beds has Dragon king in his sea palace? How many bricks of gold support his beds? And how many maidens share his beds?" Again, translate the translation into Chinese. And comparing the two Chinese versions, we can find their meanings are similar. So, the information processing pattern can deal with the problems caused by the differences of poetic composition between Chinese and English.

Still, the Chinese word “宫娥” in this poem means the pretty maids in the palace. However they may not be the concubines. So, under this circumstance, we choose the word "maiden". The translation is "And how many maidens share his beds?" This version is fluent and fit to the original Chinese meaning. There is another poem, “枯鱼过河泣, 何时悔复及! 作书与鲂䱋, 相教慎出入。” That word “鲂鱮” represents two specific fish which is no need to translate into English. Thus, the translation according to the information processing pattern is "The fish in the dry land, too late to be regretful. He told the other fish, to be careful of going."(Wang Hongyin, 2014:21-22) From these two examples, the information processing pattern can explain the meaning of a word with the specific situation and can also help the translator to leave out some insignificant words.

Another folk song “青龙大王老人家，再下哎十分的海雨救万民，已时布云午时下雨救万民 ” uses a lot of mood words. Also, its sentences are very tedious. Thus, translators can abstract the kernel and main idea of the content during the analysis stage of the information processing pattern. And the Chinese meaning of this folk song is “青龙大王, 请求您多多下雨救百姓, 在早上把云汇集, 在午时下雨” Next, in the process of synthesis, to translate the text with the linguistic features of the second language. So, the translation is "Blue dragon, the great king. Please rain hard to save men. Gather clouds in the morning. And downpours at moon." Compared with the original text their meanings are similar. From this example, it can be found that when using the information processing pattern, the translators do not have to translate word by word and catching the main idea is enough.

\section{SUMMARY}

In summary, according to all the materials of fishing songs, we conclude and summarize that the problems exist in the fishing songs are as follow: 1. The problems of the poetic composition, grammar and word order due to the differences between Chinese and English; 2. The difficulties to replace a word by an English word of the same meaning and the absence of the translation about proper names; 
3. The existence of the complex and insignificant vocabulary in the poem. Using the information processing pattern to analyze the syntax, semantics, and pragmatics of the original text. And then, add or subtract some points of the text on the basis of the original version. Finally, translate the poem into English. Through these steps, most of the problems can be solved properly and the meaning of the original text can be expressed clearly.

This study aims at providing academic materials and translation patterns, and also promoting the translation quality and advertising Zhoushan fishing songs as well. In addition, it attempts to inherit and protect the culture, and promote the cultural exchanges of Zhoushan.

\section{REFERENCES}

[1] 杨春.浅谈翻译模式的发展[J].佳木斯大学社会科学学报, 2001,19（2）

[2] 都丽丽.奈达翻译理论评述[J]，考试周刊，2008,20

[3] 苗菊、高乾.莱比锡学派的理论渊源及其贡献[J]，外国语文，2010,26(24)

[4] 张吉良.巴黎释意学派口译过程三角模型研究[J], 外语教学理论与实践, 2011,V2（2）

[5] Bell, R.T. Translation and Translating: Theory and Practice [M]. London and New York: Longman. 1991

[6] 王宏印.中国古今民歌选译[M].北京：商务印书馆，2014:21-22

Citation: Guo Yutian \& Jiadai MAO. "The Translation of Zhoushan Fishing Songs under the Background of Constructing the International Ecological Leisure Island". International Journal of Humanities Social Sciences and Education (IJHSSE), vol 5, no. 4, 2018, pp. 83-85 doi: http://dx.doi.org/10.20431/23490381.0504009 .

Copyright: (C) 2018 Authors. This is an open-access article distributed under the terms of the Creative Commons Attribution License, which permits unrestricted use, distribution, and reproduction in any medium, provided the original author and source are credited. 